\title{
長崎県上五島地域における医療供給体制の再編成と そのメカニズム
}

中 村

努
I はじめに
(1) 問題の所在
(2) 既往の研究と研究目的
II 新上五島町の医療政策
(1) 対象地域の概要
（2）長崎県に扔ける離島医療政策の概要
III 医療供給体制の再編成過程

キーワード：医療供給体制，離島，医療施設，二次医療圈，上五島地域

\section{I はじめに}

(1)問題の所在 日本の医療供給体制は，国民 皆保険制度のもとで，地域によらずニーズに合っ た医療サービスを, 誰もが相応の負担で受けられ るという公平性の維持を原則としてきた。しかし, 離島における医療供給体制は十分整備されている とはいえず，環境要因として，以下の 3 点が近年 の医療需要と供給の関係にさらなる変化をもたら している。

第 1 に, 近年, 疾病構造が継続的なケアを必要 とする糖尿病や高血圧症などの慢性疾患へと変化 していることである。従来の医療供給体制は感染 症などの急性疾患に対して, 入院治療を中心とし た医療施設の最適な配置による解決が図られてき た。しかし，治療を目的とした医療施設の最適立 地を追求するのみでは対処しにくい在宅医療や生 活支援のニーズが生じている。上記の問題は，医 療関連施設や医療従事者が不足する地方において, より深刻であると推測される。
第 2 に，地方自治体財政の悪化と高齢化である。 これにより，地域によっては画一的な政策では対 応できず，自圈内で必要な医療サービスを提供で きない不採算の医療需要が依然として残存する。 そのうち, 大都市圈に隣接する中山間地域は都市 部と地続きであるため, 都市部との一体的運営に よるサービス供給範囲の拡大が，供給効率化の手 段となりうる。一方，島嶼部で構成される医療圈 は，隔絶性と狭小性という地理的特性を有してい るため, 医療供給の範囲は島内に限定され効率的 な供給は制約される。また，患者にとって，島外 で受診することに伴う移動の肉体的，心理的，金 銭的負担はきわめて大きい。

第 3 に, ドクターヘリや医療情報システムなど 新たな搬送手段や情報技術が，医師や医療施設の 不足を補完する手段の一つとして利用できるよう になっていることである。そこで，離島内におい ては財政適正化を原則として，提供できる範囲の 医療サービスを限定し，必要に応じて他地域から 医師派遣やドクターヘリによる搬送，高度専門医 
療，遠隔画像診断といった支援を受けることが前 提とならざるを得ない。

3 点目は, 地域内外の施設が入院機能, 外来機 能，生活支援機能，調剤機能などそれぞれの役割 を分担したうえで連携する動きを伴っている。し たがって, 地域内外の諸施設を運営する関係主体 の行動から，こうした仕組みが構築されるメカニ ズムを検討することは, 地理的条件の違いに配慮 した超高齢社会における持続可能な社会保障政策 のあり方を議論することにつながる。

(2) 既往の研究と研究目的医療をはじめとす る公共的なサービスは，住民にあまねく提供され ることが望ましいが，実際には，サービスの利用 機会には地域差が生じる。そこで地理学において, 医療サービスが提供される施設のアクセシビリテ イを明らかにする研究や最適配置を求める研究が みられた。

アクセシビリティを扱った地理学的研究につい ては, 生鮮食料品にアクセスしにくいがゆえに, 生活環境の悪化の可能性を明らかにしたフードデ ザート問題がある。ところが, こうした研究は, 利用者と最寄りの小売店との距離を指標にしてお り, サービスの量と質への評価は十分ではない。 医療サービスに関して言えば，初期医療から三次 救急まで重症度に応じたサービスが，医療施設の 規模に応じて階層的に供給されている。また, 物 理的距離の制約に対して, 医師派遣や遠隔画像診 断，ヘリによる救急搬送といった代替手段が利用 可能である。サービス供給の公平性を議論するに あたっては，利用者と施設との物理的距離のみな らず，各施設から提供される医療サービスの量と 質から，その入手可能性をより詳細に検証する必 要があろう。

また，誰がどのような仕組みのもとでサービス 供給を実現するに至ったのか, そのプロセスを関 係主体の行動の地理的条件から解釈しなければ, サービス供給の維持可能性を検証できない。従来, 公共サービスを地理学から検討した研究は, 市町
村が保険者となっている介護保険を中心に，サー ビス需給における地理的差異が生ずるメカニズム を検証してきた。また，管轄自治体の対応を含め， 特定の市町村内の資源配分と活用のあり方を論じ るという政策指向性を有していた。一方，医療开 ービスはナショナルミニマムとしての性格が強い が，実際の供給にあたっては，財政移転の進む都 道府県や市町村に加えて, 国立や大学附属, 私立 医療機関の裁量によるところが大きい。

こうした関係主体の行動は地理的条件によって 大きく異なる。医薬品の流通システムを検討した 研究に拈いて, 市場規模の大きい都市部では,

ICT (Information and Communication Technology,

以下, ICT と略す)への大規模投資に経営戦略上 の意義を見出していた医薬品卸の行動が, 需要の 不確実性を解消していた。一方，人口減少が進み 市場規模が小さい離島では, 割高の配送コストを 流通業者間で分担することで医薬品へのアクセス が維持されていた。このように，離島においては 空間的制約が特に大きいことから，島内の関係主 体の協調行動によってこうした制約を克服しょう とする動きがみられる。ただ，中村が対象とした 五島市の主要な島である福江島は, 離島の中でも 人口が相対的に大きく，営業拠点が立地するほど 独立した商圈が成立しうる地域であった。

一方，同じ五島列島に属する新上五島町は，人 口やその分布に関する条件不利性が五島市より高 い。すなわち，国勢調査報告による2010年現在の 人口は，五島市の 4.1 万人に対して，新上五島町 では 2.2 万人と少ない。また，福江島は比較的平 坦な土地が多い一方, 新上五島町の主要な島の地 形は複雑で, 屈曲した海外線が多いうえに平坦地 に乏しく，人口は地理的に分散している。加えて， 新上五島町に扔ける人口 10 万人当たりの病院病床 や医師の不足は顕著で, 2010年の各值は，全国平 均（1,244床, 230 人）を大きく下回って長崎県内で 最低水準である (987床, 136人)。新上五島町にお けるこうした相対的に少ない人口の分散的な分布, 
少ない医療資源といった地域特性が，医療サービ ス供給の効率化をいっそう難しくしており, サー ビス維持のために島内外の関係主体の協調の必要 性はより切迫しているものと推測される。

したがって, 当該自治体というローカルな地理 的スケールにとどまらず，本土一離島間や市町村 間といったより広域のスケールも視野に入れた議 論が必要となる。市町村といった地方自治体は財 源や人材の不足から，管轄地域外の資源も活用す ることによって，患者の医療ニーズを充足してい る場合が多い。そのため, 離島の医療供給体制の 再編成というローカルな事象は, ナショナルレベ ルの厚生労働省や総務省を中心とした医療政策の 影響，本土に立地する国立病院，大学病院による 支援に加えて、リージョナルな地理的範囲を管轄 する県や近隣自治体による離島医療機関の運営と いう重層的なスケールからとらえなければ，離島 の医療供給体制における再編成のダイナミズムを 理解できない。

そこで本稿では，長崎県上五島地域を事例とし て, 条件不利地域である離島における医療供給体 制の再編成のプロセスとそのメカニズムを明らか にすることを目的とする。とりわけ，上五島地域 内外の各主体がどのようにして経営の合理化を図 りながら医療サービスの公平性の維持に努めてい るのかに焦点を当てる。上五島地域は将来の人口 減少と高齢化を見据えて, 市町村合併を契機に, いち早く医療供給体制を再編成しており，本稿の 目的を明らかにするための適切な事例と判断した。 データの分析にあたって，2013年 5 月に医療関連 施設や新上五島町役場に対してヒアリングを実施 するとともに，資料の提供を受けた。

以下，第II章では，従来の新上五島町の医療供 給体制を概観する。第正章では，医療供給体制の 再編成過程を検証し，第 IV 章では，医療供給体制 の再編成に向けた，関係する各主体の行動を長崎 県特有の経営環境から解釈する。第 $\mathrm{V}$ 章では, 医 療供給体制の再編成プロセスを重層的なスケール
から考察することで，持続可能な社会保障のあり 方を考える上での論点を提示する。

\section{II 新上五島町の医療政策}

(1) 対象地域の概要 新上五島町は, 九州の西 端, 長崎県五島列島の北部に位置する。中通島と 若松島を中心として，7つの有人島と60の無人島 から構成されている。上五島地域は離島であるこ とに加え，急峻な山々が連なり，平地にそしいとい う地形的制約を抱えている。総面積は $213.98 \mathrm{~km}^{2}$ （2010年10月 1 日現在）であり，民有地の地目別で は山林 $74.9 \%$ ，畑 $15.6 \%$, 宅地 $4.1 \%$ (2009年 1 月 1 日現在）となっている。

新上五島町は2004年 8 月, 旧 5 町 (若松町, 上 五島町, 新魚目町, 有川町, 奈良尾町）が合併したこ とにより誕生した。町外との交通手段は2006年 3 月末に上五島空港の定期航路が廃止されたことに より，海上公共交通に限定されている。海上公共 交通は 4 つの基幹航路（奈良尾～長崎, 鯛ノ浦〜長 崎, 有川〜佐世保, 青方 ·若松〜博多) に加え, 離島 間等をつなぐ民間航路と 1 つの公営航路で形成さ れている。1991年に若松大橋が完成したことによ り, 中通島と若松島は陸路で結ばれ, 上五島地域 の一体性は高まった。

しかし，国勢調査報告による人口は1960年の 5.7 万人から, 2010 年の 2.2 万人と年に約 700 人の ペースで減少を続けている。一方, 高齢者人口は, 同期間に 3,230 人から 7,382 人へと増加したことに 伴い, 高齢化率は $5.7 \%$ から $33.4 \%$ へと全国平均 (23.0\%) を大きく超えて上昇した。その要因は, 基幹産業である水産業の低迷を背景に，若年層が 地域外に流出していることに加えて, 出生数が低 下していることにある。

旧町別に人口分布の状況をみると，1980年当時, 有川地区の 9,882 人から奈良尾地区の 5,383 人まで 人口が比較的分散していた（第 1 図）。2000年現在, 町内の人口が減少傾向を示すものの, 町役場本庁 が立地している上五島地区（6,129人）と隣接する 


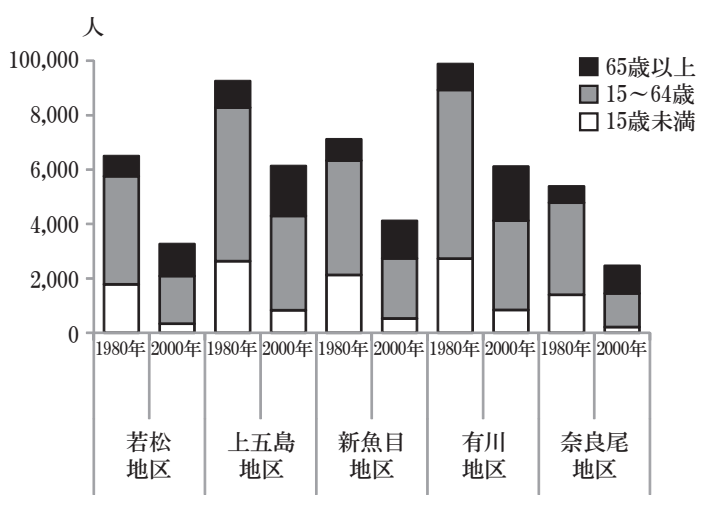

第 1 図 新上五島町地区別にみた人口構成の変化

Figure 1. Changes in demographic composition by district in Shin-Kamigoto Town

資料：国勢調查により作成。

有川地区（6,106人）に人口が集中する傾向がより 強まっている。ただ, 奈良尾地区 $(2,467$ 人) や若 松地区 $(3,260$ 人) , 新魚目地区 $(4,112$ 人) といっ た周辺部にも人口が分散している。高齢化の進展 は全地区において確認できる。どの地区において も，人口の減少にもかかわらず，2000年の65歳以 上人口は，1980年と比較して 2 倍前後の伸びを示 しており，医療ニーズの増大は全地区に共通した 課題になっていると推測される。

長崎県における医療供給体制の特徴は, (1)人口 当たりの医療施設や病床数, 医療従事者数といっ た医療資源は総じて多いこと, (2)長崎，佐世保県 北, 県央と, 県南, 離島地域の医療資源の地域差 が大きいことである。例えば，2010年における人 口 10 万人当たりの医師数は, 長崎県において 284.7 人と全国平均（230.4人）を 54 人も上回るが, 本土部医療圈では 296.6 人に対して, 離島部医療 圈（五島, 上五島, 壱岐, 対馬）では 165.5 人であり, 本土と離島の地域差は依然として大きい。こうし た傾向は, 病院を除いた医療施設や病床, 他の医 療従事者においても同様にみられる。

新上五島町では，医師や看護師の勤務環境や生 活環境が悪化しているために補充しにくい状況に ある。例えば，同町における2008年の病院勤務医 師一人当たりの病床数は 12.3 床と, 全国平均
（9.2床）や長崎県平均（11.3床）に比べて多く, 医 師一人当たりの負担が大きくなっている。

2008年以前, 町内の公的医療機関として, 上五 島病院（186床）を中心に, 有川病院 (50床), 奈 良尾病院（60床）の公立病院のほか，19床の入院 病床を有する若松国保診療所と新魚目国保診療所, 外来診療のみの国保榎津診療所, さらに仲知, 津 和崎, 東神ノ浦, 岩瀬浦, 崎浦の 5 力所の僻地診 療所, 日島出張診療所が立地していた（第2図）。 公的 3 病院は, 初期医療, 初期救急から二次救急 医療，健康診断などの保健予防活動，療養等の高 齢者医療までを担っていた。入院機能を有する医 療機関は，それぞれ合併前の旧町ごとに 1 力所ず つ分散立地していた。それらはまた，僻地診療所 への医師派遣による支援を通じて，医療機関への アクセスの維持に努めていた。

しかしながら，患者の受療行動は島内で完結せ ずに島外へ流出している。全町民の 3 割を占める 国民健康保険患者による，地区別にみた医療機関 の利用状況において，入院患者の 5 割，外来患者 の 2 割が島外にある医療機関を受診しており，島 外の医療資源への依存度は高い（第 1 表）。第一に, 入院に関して, いずれの地区においても患者の約 半数が島外の医療機関を選択している。新上五島 町内で最大の病床数をもつ上五島病院への入院患 者は島内全域のおいて一定の割合を占める。また, 病院が立地している奈良尾地区や有川地区におい ては，地区内の病院を選択する割合が他地区より も高い。それにもかかわらず，島外の医療機関で 入院する患者の割合が相対的に高いことが，新上 五島町の受療行動の特徵の一つとなっている。こ の理由としては, 一部の重症患者や精神疾患患者 など，島内の医療機関では入院治療に対応できな いために，島外の医療機関を選択せざるを得ない ケースと, 島内の医療機関の専門性や混雑状況な どを勘案して，より専門性の高い医師や設備をそ ろえた医療機関や待ち時間の少ない医療機関を島 外に求めるケースとが混在しているといゔ。 


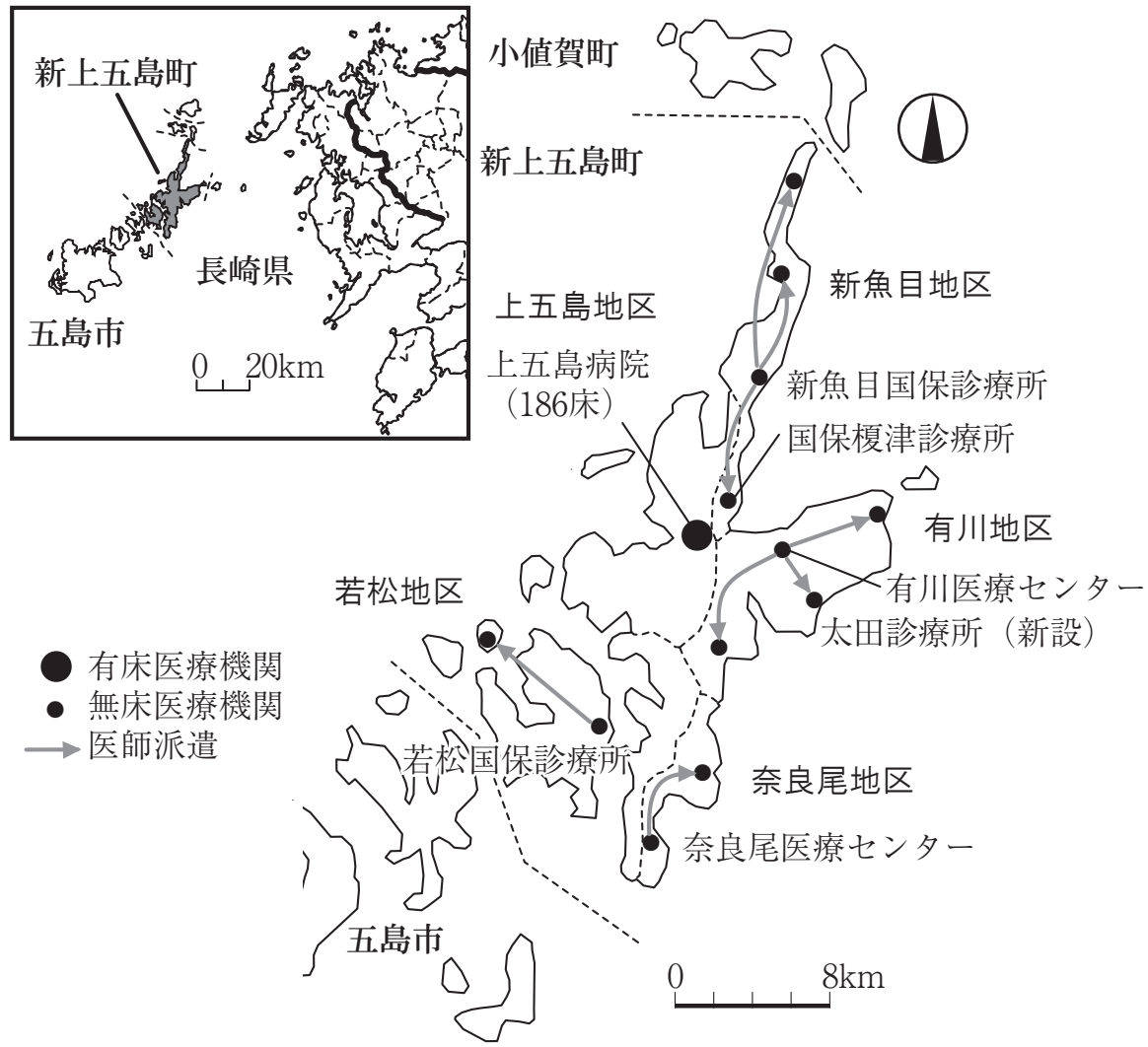

第 2 図 新上五島町における医療機関の分布

Figure 2. Distribution of medical institutions in Shin-Kamigoto Town 資料：長崎県新上五島町役場健康保険課の資料により作成。

第二に，外来に関して，入院ほどではないが, 各地区の患者の 2 割前後が島外にある医療機関を 受診している。一般的に，外来は入院よりも受療 圈が狭く，都道府県は地域医療計画において，日 常の健康管理やかかりつけ医による初期診療を提 供する地理的範囲を, 一次医療圈として市区町村 に設定している。しかし，島外の医療機関を受診 する割合は, 若松地区 (27.1\%), 奈良尾地区 (26.4 \%)において特に高い。加えて，島内の医療機関 を受診する患者においても, 病院の外来を選択す る割合が奈良尾地区 (69.2\%), 有川地区 (67.0\%), 上五島地区 $(59.1 \%)$ において高い。このことか ら, 病院は入院と外来の双方の機能において果た す役割が大きいうえに，患者の受療圈は本土の医 療機関を含めた広域の範囲にわたっていることが
第 1 表 国保患者の旧町別医療機関利用状況 (2007年度) Table 1. Status of medical institutions utilization situation by national insurance subscribers by district as of 2007

\begin{tabular}{|c|c|c|c|c|c|c|}
\hline \multirow{2}{*}{\multicolumn{2}{|c|}{$\begin{array}{c}\text { 入院患者数 } \\
\text { (人) }\end{array}$}} & \multicolumn{5}{|c|}{ 医療機関別利用割合（\%) } \\
\hline & & \begin{tabular}{|l} 
上五島 \\
病 院
\end{tabular} & \begin{tabular}{|l} 
奈良尾 \\
病
\end{tabular} & 有川病院 & $\begin{array}{l}\text { 上五島内 } \\
\text { 診療所等 }\end{array}$ & 上五島外 \\
\hline 上五島 & 874 & 51.9 & 0.3 & 0.9 & 0.7 & 46.1 \\
\hline 有川 & 881 & 37.2 & 0.8 & 10.6 & 0.3 & 51.3 \\
\hline 新魚目 & 523 & 42.6 & 0.0 & 1.0 & 11.7 & 44.9 \\
\hline 若松 & 484 & 32.6 & 11.4 & 0.6 & 4.8 & 50.6 \\
\hline 奈良尾 & 477 & 19.1 & 27.0 & 0.0 & 0.2 & 53.7 \\
\hline
\end{tabular}

\begin{tabular}{|c|c|c|c|c|c|c|}
\hline \multirow{2}{*}{\multicolumn{2}{|c|}{$\begin{array}{c}\text { 外来患者数 } \\
\text { (人) }\end{array}$}} & \multicolumn{5}{|c|}{ 医療機関別利用割合（\%） } \\
\hline & & \multirow{2}{*}{\begin{tabular}{|c|}
\multicolumn{2}{|c|}{ 上五島 } \\
病
\end{tabular}} & \multirow{2}{*}{$\begin{array}{c}\text { 奈良尾 } \\
0.2\end{array}$} & \multirow{2}{*}{$\begin{array}{c}\text { 有川病院 } \\
0.7\end{array}$} & \multirow{2}{*}{$\begin{array}{c}\frac{\text { 上五島内 }}{\text { 診療所等 }} \\
23.6\end{array}$} & \multirow{2}{*}{$\begin{array}{c}\text { 上五島外 } \\
17.2\end{array}$} \\
\hline 上五島 & 15,590 & & & & & \\
\hline 有川 & 17,008 & 36.6 & 0.3 & 30.1 & 17.1 & 15.9 \\
\hline 新魚目 & 11,683 & 34.6 & 0.1 & 1.3 & 50.4 & 13.6 \\
\hline 若松 & 10,955 & 32.1 & 7.4 & 0.2 & 33.2 & 27.1 \\
\hline 奈良尾 & 8,463 & 22.5 & 46.7 & 0.0 & 4.3 & 26.4 \\
\hline
\end{tabular}

資料：長崎県新上五島町『医療再編計画資料別冊』長崎県新 上五島町，2010により作成。 


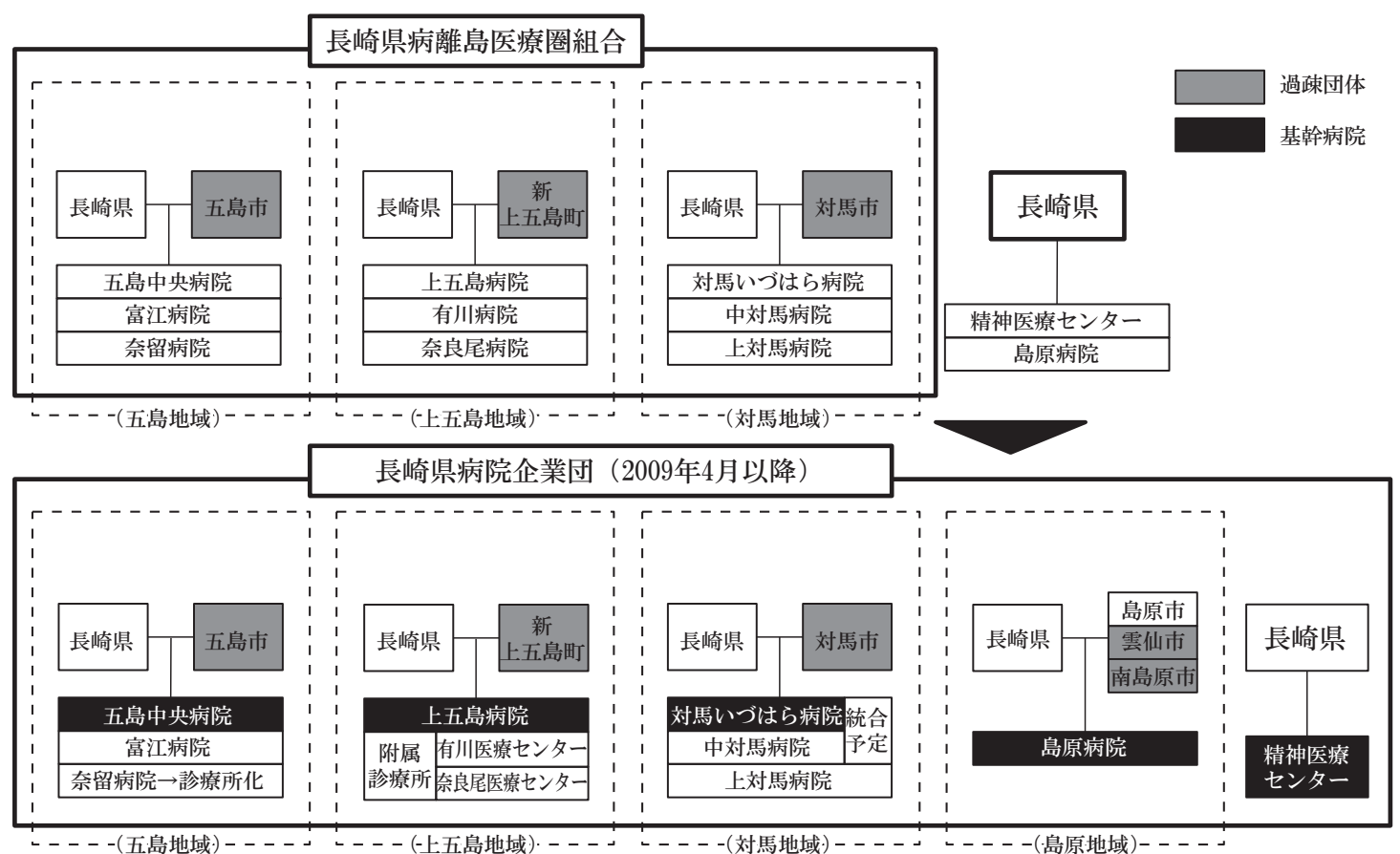

第 3 図 長崎県病院企業団の組織体制

Figure 3. Organization of Nagasaki Hospital Agency

注 : 財政難と医師不足を抱えていた島原地域の旧県立島原病院は, 離島医療圈組合病院あり方検討懇話会からの提言を受けて新た に企業団に加わった。

資料：長崎県病院企業団から提供された組織体制や経営概況を解説した資料により作成。

わかる。国民健康保険の主な構成員は従来，一次 産業従事者であったが, 現在では退職者や高齢者 などの低所得者の加入が主であり，国民健康保険 の財政運営は峳しく，2008年度には基金の余剩が なくなったため，一般会計から借り入れている状 況にある。

（2）長崎県における離島医療政策の概要 各都 道府県は地域医療計画によって, 入院医療を完結 させるための地理的範囲として二次医療圈を設定 している。しかし, 長崎県の 8 つの二次医療圈の うち, 離島で構成される 4 つの二次医療圈は, 少 子高齢化と医師不足のために，自圈内で必要な医 療サービスを提供するには限界がある。そこで, 離島地域の医療計画は, 本土の支援を受けながら, 必要最小限の医療サービスを維持してきた。長崎 県における離島医療政策の支援内容は，(1)医療機 関の運営, (2)医師の確保，(3)へリによる島外搬送
手段の確保，(4)医療情報システムの導入に集約さ れる。

長崎県では, 県, 大学, 地方自治体が一体とな って離島医療の充実を図ってきた経緯がある。五 島，壱岐，対馬，生月の医療施設が不足する離島 においては，長崎県と壱岐，五島，対馬の離島市 町が一体となって，病院を経営する目的で1968年 に一部事務組合である長崎県離島医療圈組合を設 立し, 施設の老朽化の解消や増床による整備を図 っている（第 3 図）。また，医師確保のため，1970 年に長崎県医学修学資金貸与制度，1972年に全国 的に自治医科大学派遣制度が創設された。

1979年には, 長崎県医学修学生, 自治医科大学 生として医師免許を取得した養成医が，長崎県の 離島および僻地医療の向上，発展に貢献すること を目的として, 長崎県離島医療医師の会（もく也 い会）を設立した。会員数164名（2008年現在）の 
任意団体であり, 離島, 僻地医療に従事する医師 の養成, 学生教育, 研究, 研修助成, 医療に関す る諸問題の解決に取り組んでいる。加えて, 1984 年に巡回診療船「しいぼると」が建造されるなど, 長崎県の医師不足を解消するための施策がとられ てきた。

また, 長崎県は, 離島, 僻地における公立診療 所の医師確保など，地域医療の確保を支援するた め，2004年に離島・へき地医療支援センターを設 置し, 常勤医師や代診医師の派遣を行うなど医療 支援を行っている。診療所の医師が休暇や出張の 際には，診療所から代診医師の派遣依頼を受けた 離島および僻地の市町の所管部署が, 同センター に医師の派遣を要請している。さらに, 上五島病 院にある15の診療科のうち, 循環器内科, 神経内 科, 泌尿器科, 耳鼻咽喉科, 皮膚科は長崎大学病 院からの診療派遣により対応している。脳神経外 科や心臓血管外科, 心筋梗塞に対する心蔵カテー テルによる治療, 核医学検査や放射線治療は同病 院では設備，専門医を有していないため，本土病 院と連携し，迅速な患者搬送に努めている。

離島から本土医療機関への三次救急患者の搬送 には，1999年10月に導入された県防災へリと， 2006年12月に運用されたドクターヘリによるへリ コプター搬送システムが活用されている。また, 緊急搬送すべきかどうかの判別が困難な場合に備 えて，遠隔画像診断システムを利用している。同 院で対応できない脳神経外科や心臓血管外科疾患, 心筋梗塞患者などが発生した場合，画像伝送シス テムで長崎大学病院や国立病院機構長崎医療セン ター（以下，長崎医療センターと略す）にデジタル 化した画像を送り，専門医と相談して治療方針や 患者搬送の適応を決定する。搬送の必要がある場 合には，海上自衛隊や県防災へリ，ドクターヘリ で本土専門病院へ患者搬送を行う。

こうした一連の離島医療政策は，医師不足にあ っても本土と同様の医療サービスを提供できるよ う，医療制度や医療環境の変化に応じて時ととも
に深化しており，長崎システムとして全国から注 目されている。

\section{III 医療供給体制の再編成過程}

(1)市町村合併以降 新上五島町の行財政を取 り巻く環境は，依然として厳しい見通しである。 同町の財政状況は，合併後に実施された2005年度 から 2009年度の 5 力年にわたる行財政改革を経て, 危機的な状況は脱したものの，依然として多額の 町債残高や依存度の高い地方交付税に係る合併支 援措置（算定替）の終了を前提とした長期的な視 点からの財政運営が必要となっている(第 2 表)。 総務省によると，2010年度における長崎県の財政

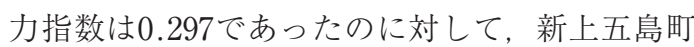
のそれは，0.274に過ぎず，基準財政需要額が基 準財政収入額を大きく上回っている状況である。

特別交付税の不採算地区分は，2006年度におい て, 有川病院, 奈良尾病院で計約 7,500 万円であ ったが，合併による特例措置であり，2009年度を もって終了した。一方, 2006年度の若松, 新魚目 両町立診療所の医業収入は, 合計約 2 億円の赤字 であった。診療所における外来患者数，入院患者 数ともに毎年減少しており，2008年度の病床利用 率は，若松診療所が $37 \%$, 新魚目診療所が $17 \%$ と 低く, 今後も減少が予想されていた (第 3 表)。

また，若松診療所において，長崎大学から常駐 で医師 1 名を派遣していたが，2009年 4 月以降， 週 3 日の派遣となったため, 医師が 1 名体制とな り，常勤環境の悪化が懸念されていた。一方，新 魚目診療所は，2006年度に退職した医師の欠員補 充ができないことから，医師が 1 名の状態が続い ていた。こうした状況を踏まえ，2005年12月に策 定された新上五島町行財政改革大綱の中で, 若松, 新魚目両診療所について, 入院部門の廃止および 経営形態の統一化が取り組むべき課題として挙げ られた。

2006年11月，長崎県離島医療圈組合は，外部有 識者でつくる県立及び離島医療圈組合病院あり方 
第 2 表 新上五島町における医療供給体制の再編成プロセス

Table 2. Health care restructuring process in Shin-Kamigoto Town

\begin{tabular}{|c|c|c|c|}
\hline 年 & 長崎県 & $\begin{array}{c}\text { 長崎県離島医療圈組合（2009年 } 3 \text { 月まで） } \\
\text { 長崎県病院企業団（2009年 } 4 \text { 月以降） }\end{array}$ & 新上五島町 \\
\hline 2004 & & 4 月：地方公営企業法の全部適用を実施 & $\begin{array}{l}8 \text { 月： } 5 \text { 町 (若松町, 上五島町, 新魚目 } \\
\text { 町, 有川町, 奈良尾町) が合併して新上 } \\
\text { 五島町が誕生 }\end{array}$ \\
\hline 2005 & & & 12月：新上五島町行財政改革大網策定 \\
\hline 2006 & $\begin{array}{l}3 \text { 月：県立病 院 新 運 営計 画 } \\
(2006 \text { 2010年度 }) \\
3 \text { 月：長崎県保健医療計画策定 } \\
(2006 〜 2010 \text { 年度 }) \\
\text { 11月：県立及び離島医療圏組合 } \\
\text { 病院あり方検討懇話会設置 } \\
12 \text { : ドクターヘリのの連用開始 }\end{array}$ & $\begin{array}{l}3 \text { 月：県立病院新運営計画を策定 } \\
\text { 11月：外部有識者会議「県立及び離島医療圈組 } \\
\text { 合病院あり方検討懇話会」を設置 } \\
\text { (平成19年 } 7 \text { 月までに懇話会を } 8 \text { 回開催) }\end{array}$ & $\begin{array}{l}3 \text { 月 : 新上五島町行財政改革実施計画 } \\
\text { (新上五島町集中改革プラン) 策定 }\end{array}$ \\
\hline 2007 & $\begin{array}{l}7 \text { 月 : 県立及び離島医療圈組合 } \\
\text { 病院あり方検討懇話会報告書提 } \\
\text { 出 }\end{array}$ & $\begin{array}{l}\text { 11月：県立及び離島医療圈組合病院の基本方針 } \\
\text { を知事が発表 (県立 } 2 \text { 病院と離島医療圈組合 } 9 \\
\text { 病院は, 県と地元 } 5 \text { 市 } 1 \text { 町が共同体を設立し運 } \\
\text { 営すべき) }\end{array}$ & 6月：医療体制のあり方検討委員会設置 \\
\hline 2008 & & & 3月：太田診療所を開設 \\
\hline 2009 & $\begin{array}{l}3 \text { 月：長崎県立病院改革プラン } \\
\text { 策定（2009〜2011年度） }\end{array}$ & $\begin{array}{l}3 \text { 月：長崎県離島医療圈組合解散 } \\
4 \text { 月 : 長崎県病院企業団設立。矢野企業長就任 } \\
11 \text { 月 : 有川病院を無床診療所化し, 上五島病院 } \\
\text { 附属有川医療センターに改称。人工透析室, リ } \\
\text { ハビリテーション室等を整備 }\end{array}$ & $\begin{array}{l}\text { 6月：新上五島町医療再編実施計画策定 } \\
7 \text { 月〜 } 8 \text { 月：小学校区ごとの住民説明会 }\end{array}$ \\
\hline 2010 & & $\begin{array}{l}4 \text { 月：上五島病院療養病床を一般病床 · 亜急性 } \\
\text { 期病床に変更 }\end{array}$ & $\begin{array}{l}\text { 10月：新魚目診療所を無床化 } \\
\text { 10月 : 若松診療所を無床化 }\end{array}$ \\
\hline 2011 & $\begin{array}{l}3 \text { 月: 長崎県医療計画策定 } \\
(2011 \sim 2015 \text { 年度 }\end{array}$ & $\begin{array}{l}4 \text { 月：奈良尾病院を無床診療所化し, 上五島病 } \\
\text { 院附属診療所奈良尾医療センターに改称 }\end{array}$ & $\begin{array}{l}3 \text { 月 : 新上五島町第 } 2 \text { 次行財政改革大綱 } \\
\text { 策定 } \\
7 \text { 月：新上五島町第 } 2 \text { 次行財政改革実施 } \\
\text { 計画策定 }\end{array}$ \\
\hline 2012 & & $\begin{array}{l}3 \text { 月：長崎県病院企業団中期経営計画策定 } \\
(2012 \text { - } 2016 \text { 年度 }) \\
\text { 4月：上五島病院附属診療所奈良尾医療センタ } \\
\text { —を新築移転。米倉企業長就任 }\end{array}$ & \\
\hline
\end{tabular}

資料：長崎県『長崎県地域医療再生計画（離島圈域）』長崎県, 2010, 長崎県『長崎県医療計画』長崎県, 2011, 長崎県病院局 『長崎県立病院改革プラン』長崎県病院局，2009，新上五島町医療体制のあり方検討委員会『新上五島町医療体制のあり方検 討委員会報告書 (答申書)』新上五島町医療体制のあり方検討委員会, 2008, 長崎県新上五島町『新上五島町医療再編実施計 画』長崎県新上五島町，2009，長崎県新上五島町『新上五島町第 2 次行財政改革大綱』長崎県新上五島町，2011により作成。 また, 長崎県病院企業団長の就任時期については長崎県病院企業団への聞取り調査, 新上五島町における小学校区ごとの住民 説明会の時期については上五島病院への聞取り調查により作成。

第 3 表 医療機関の 1 日当たりの平均患者数

Table 3. Average number of patients seen per day by medical institution

\begin{tabular}{|c|c|c|c|c|c|c|c|c|c|c|c|c|}
\hline & \multicolumn{2}{|c|}{ 上五島病院 } & \multicolumn{2}{|c|}{ 有川病院 } & \multicolumn{2}{|c|}{ 奈良尾病院 } & \multicolumn{2}{|c|}{ 若松診療所 } & \multicolumn{2}{|c|}{ 新魚目診療所 } & \multicolumn{2}{|c|}{ 榎津診療所 } \\
\hline & 2008年度 & 2012年度 & 2008年度 & 2012年度 & 2008年度 & 2012年度 & 2008年度 & 2012年度 & 2008年度 & 2012年度 & 2008年度 & 2012年度 \\
\hline 外来 (人) & 526.1 & 531.3 & 107.9 & 138.2 & 93.4 & 101.6 & 55.8 & 43.9 & 39.9 & 28.6 & 36.5 & 30.4 \\
\hline 入院 $($ 人) & 149.8 & 153.3 & 15.7 & 0.0 & 18.6 & 0.0 & 7.1 & 0.0 & 3.3 & 0.0 & 0.0 & 0.0 \\
\hline $\begin{array}{l}\text { 病床利用 } \\
\text { 率 (\%) }\end{array}$ & 80.5 & 83.3 & 31.4 & 0.0 & 31.0 & 0.0 & 37.4 & 0.0 & 17.4 & 0.0 & 0.0 & 0.0 \\
\hline
\end{tabular}

資料：2008年度のデータについては, 長崎県新上五島町『新上五島町医療再編実施計画』長崎県新上五島町, 2009により作成, 2012年度のデータについては, 聞取り調査により作成。 
検討懇話会を設置し, 病院のあり方について調査, 検討を行い, 2007年 7 月までに懇話会を 8 回開催 した。その結果, 同懇話会は長崎県と組合に対し て, 組合病院について急性期入院医療を担う医療 機関と外来機能を中心とする医療機関に機能分担 すべきとし, 県立 2 病院（島原病院, 精神医療セン ター）は従来通りとしたものの, 対馬市, 五島市, 新上五島町に 3 カ所ずつある組合運営の 9 病院の 病床再編や集約を提言した。

2007年12月には総務省から公立病院改革ガイド ラインが示され，病院事業を設置する地方公共団 体に対して2008年度内に改革プランを策定し, 経 営改革に取り組むよう要請された。このガイドラ インに拈いて, 一般病床および療養病床の病床利 用率が扮扮むね過去 3 年間連続して $70 \%$ 未満とな っている病院については, 病床数の削減, 診療所 化等の抜本的な見直しを行うことが適当であり， 病床数が過剩な二次医療圈内に複数の公立病院が 所在する場合には，再編，ネットワーク化により 過剩病床の解消を目指すべきである，とされた。

2008年12月に総務大臣による長崎県病院企業団 の設立許可が下りたことを受けて，2009年 4 月に 長崎県と島原地域, 五島地域, 対馬地域の市町が 一体となって病院を経営する長崎県病院企業団を 設立して, 県立 2 病院と離島医療圈組合 9 病院の 運営にあたることになった (第 3 図)。共同体の運 営形態としては, 地方公営企業法を全部適用した 一部事務組合（企業団）が採用された。新上五島 町内に立地する 3 病院についても, 新たに設立さ れた長崎県病院企業団によって運営されることに なった。

2007年 6 月，町立診療所と企業団病院を含めた 町全体の医療体制のあり方を検討することを目的 として, 上五島病院の名誉院長を委員長とした 15 名で構成する「医療体制のあり方検討委員会」が, 新上五島町の依頼を受けて設置された。同委員会 は関係諸機関および地域住民から幅広い意見を聴 取するため, 2007年 7 月から 2008年 3 月までのべ
7 回の会議を開催し, 町立診療所および離島医療 圈組合病院のあり方について, 調査, 検討を行っ た。その結果，まとめられた意見は，2008年 3 月， 報告書として新上五島町に提出された。この報告 書の提出を受けて, 新上五島町は2009年 6 月, 2009年度から2011年度の 3 力年間を計画期間とす る「新上五島医療再編実施計画」を策定した。

(2) 新上五島医療再編実施計画の実施 新上五 島医療再編実施計画の基本的な目標は，(1)現在あ る医療機関について, 既存の施設は残し, 機能を 変えるなど有効な活用を図ること, (2)企業団病院 については, 上五島病院を基幹病院として, 機能 分担による医療の継続を図ること, (3)疾病予防や 早期発見の原則から, 各病院, 診療所とも健診や 保健業務を継続的に実施すること, (4)安全, 安心 の医療体制の原則から，救急搬送は30分以内を目 途とすること,の 4 点であった。

新上五島医療再編実施計画に基づき，新上五島 町は2009年 7 月から 8 月にかけて, 医療施設から 入院ベッドをなくす，無床化による入院機能の低 下が懸念された小学校区ごとに計15回の住民説明 会を開き，上五島病院院長を含めて，計 1,100 名 の住民に対し計画の理解を求めた。住民からは, 入院施設までのアクセスが悪くなることによる通 院のための交通利便性の確保, 安心して出産でき る産婦人科医師の確保, 人工透析機能の維持, 入 院病床の維持などの意見や要望があったという。

有川地区には 3 力所の小学校区があり, それぞ れの校区において，一回ずつ説明会を開いた結果， 住民からの理解が得られた。そして, 当初計画の 予定通り，2009年11月，有川病院は無床診療所に 変更されるとともに，上五島病院附属有川医療セ ンターに改称された。しかし，奈良尾地区につい ては, 上五島病院から $24 \mathrm{~km}$ 離れている奈良尾病 院の無床化に対し，入院施設へのアクセシビリテ イが低下することを懸念しての反対意見が多かっ たため，2011年 4 月まで計画の実施が延期された。

入院機能は基幹病院である上五島病院 (186床) 
第 4 表 新上五島町における医療機関の機能

Table 4. Function of medical institutions in Shin-Kamigoto Town

\begin{tabular}{|c|c|c|c|c|c|}
\hline \multirow{2}{*}{ 施設名 } & \multicolumn{2}{|c|}{ 病床数 } & \multicolumn{2}{|c|}{ 医師数 } & \multirow{2}{*}{ 機能（2013年） } \\
\hline & 2008年 & 2013年 & 2008年 & 2013年 & \\
\hline 上五島病院 & $\begin{array}{l}\text { 一般132床 } \\
\text { 療養50床 } \\
\text { 感染症 } 4 \text { 床 }\end{array}$ & $\begin{array}{l}\text { 一般182床 } \\
\text { 感染症 } 4 \text { 床 }\end{array}$ & 19人 & $\begin{array}{c}20 人 \\
\text { 研修医 } 3 \text { 人 }\end{array}$ & $\begin{array}{l}\text { 救急告示病院 } \\
\text { へき地医療拠点病院 } \\
\text { 災害拠点病院 } \\
\text { 臨床研修病院 } \\
\text { 第 } 2 \text { 種感染症指定医療機関 } \\
\text { 訪問看護ステーション併設 }\end{array}$ \\
\hline $\begin{array}{l}\text { 有川病院 } \\
\text { ）有川医療センター }\end{array}$ & 一般50床 & 0 床 & 3 人 & 3 人 & 1 次医療 \\
\hline $\begin{array}{l}\text { 奈良尾病院 } \\
\rightarrow \text { 奈良尾医療センター }\end{array}$ & 一般60床 & 0 床 & 2 人 & 1 人 & 1 次医療 \\
\hline 若松診療所 & 19床 & 0 床 & 1 人 & 2 人 & 1 次医療 \\
\hline 新魚目診療所 & 19床 & 0 床 & 1 人 & 1 人 & 1 次医療 \\
\hline 榎津診療所 & 0 床 & 0 床 & 1 人 & 1 人 & \\
\hline 沖知へき地診療所 & 0 床 & 0 床 & 非常勤 & 非常勤 & 火曜日午後診療 \\
\hline 津和崎へき地診療所 & 0 床 & 0 床 & 非常勤 & 非常勤 & 木曜日午後診療 \\
\hline 東神ノ浦へき地診療所 & 0 床 & 0 床 & 非常勤 & 非常勤 & 木曜日午後診療 \\
\hline 岩瀬浦診療所 & 0 床 & 0 床 & 非常勤 & 非常勤 & 隔週火曜日午後診療 \\
\hline 太田診療所 & 0 床 & 0 床 & 非常勤 & 非常勤 & 月曜日午後診療 \\
\hline 日島出張診療所 & 0 床 & 0 床 & 非常勤 & 非常勤 & 水曜日午後診療 \\
\hline
\end{tabular}

資料：2008年のデータについては，長崎県新上五島町『新上五島町医療再編実施計画』長崎県新上五島町，2009 により作成，2013年のデータについては，聞取り調査により作成。

に集約される一方，2009年11月に有川病院（現有 川医療センター)，2010年10月に新魚目診療所と若 松診療所，2011年 4 月に奈良尾病院（現奈良尾医 療センター）がそれぞれ無床化された（第 2 図）。 その結果, 同町内に拈りる病床数の合計は, 334 床から186床にほぼ半減した。

一方，上五島病院では，医師数が2010年 4 月の 17 人から 2013 年には 23 人（内科 7 人，外科 4 人，整 形外科 3 人, 産婦人科 2 人, 小児科 2 人, 眼科 1 人, 精神科 1 人, 研修医 3 人) に増加した（第 4 表）。こ れにより, 病院勤務医師一人当たりの病床数は, 同期間に10.9床から8.1床へと，全国平均を下回 る水準に低下した。また，上五島病院の看護師不 足も有川病院および奈良尾病院の無床化に伴う看 護師の集約により解消され，高い診療報酬が得ら れる看護師の配置基準を満たすことができた。

他方，無床化した有川医療センターは，人工透 析機能を 6 床増加して20床とし, 東神ノ浦へき地 診療所, 崎浦地区へき地診療所, 太田診療所へ医
師の派遣を行っている。2009年度に6,400万円の 赤字だった有川医療センターの経常収支は，2010 年度には 1,000 万円の黒字に転換した。奈良尾医 療センターは, 岩瀬浦診療所への医師の派遣およ び訪問看護ステーションの設置により，在宅医療 を提供する体制を整備した。さらに，奈良尾医療 センターについては，2012年 4 月，国の地域医療 再生臨時特例交付金を活用することで，総事業費 3 億900万円をかけて, 高台から奈良尾港近隣の 通院利便地に新築移転した。また，診察室 3 室の ほか, 救急処置室, リハビリ室などが整備された。 新魚目診療所では，2名の医師が 3 カ所の診療 所に週一回交替で出向き，一次医療と予防医療に 取り組んでいる。若松診療所においても，2013年 4 月以降， 1 名の医師が増え，日島診療所に扔け る週一回の診療を行うこととなった。

一方, 三次救急医療や精神科の入院機能につい ては，新上五島町内に対応できる施設が存在しな いため，本土の医療資源を活用することを前提と 
した豊富な離島への支援が存在していた。それら は，本土に立地する三次医療機関である長崎医療 センターヘのヘリコプターによる救急搬送, 高度 専門医療，遠隔画像診断を含む。また，長崎医療 センターと長崎大学病院は, 離島への医師派遣に おいて主要な役割を果たしてきた。

加えて，長崎県内で普及している医療情報シス テムを通じて, 島内外の病院と診療所間の情報共 有が図られている。島外では2004年11月，上五島 病院が同システムの利用を開始し，本土の長崎大 学病院および長崎医療センターの診療情報にもア クセスできるようになった。また，島内において は2011年 7 月以降，患者の同意があれば，上五島 病院の診療情報が有川医療センター，奈良尾医療 センターに加えて, 薬局 2 施設と患者の主な退院 先である介護施設 1 施設に公開できるようになっ た。2013年 7 月現在，新上五島におけるシステム 登録患者数は 314 人である。特に専門的医療にか かる患者は, 本土の医療機関と併院する場合が多 く，自身の訬療情報について具体的に伝達するこ とが困難であることから，システムの利用に積極 的であるというे。

こうして, 新上五島町の医療供給は, 旧町ごと に入院病床を有する医療機関が分散立地する体制 から，遠隔医療と医師派遣，救急搬送を活用しな がら，特定の医療機関に入院機能を集約した階層 的な体制へと再編成された。

\section{IV 医療供給体制の再編成の仕組み}

（1）各主体の行動 新上五島町において，医療 再編実施計画が当初の計画通りに実施された。そ して, 町内の医療関連施設は，それぞれの機能を 分担しながら相互に連携することで，サービス水 準の維持と経営改善の両立が図られた。当該計画 がスムーズに実施された背景には，計画実施以前 の新上五島町, 長崎県病院企業団, 本土医療機関, 上五島病院による離島医療の確保に向けた協調行 動があった。以下，それぞれの主体の行動を長崎
県特有の経営環境に焦点を当てて, 詳細に検討す る。

新上五島町では，市町村合併に伴う合併特例措 置の終了を踏まえた行財政改革を積極的に行う必 要があった。旧町ごとにあった組合病院や有床診 療所の病床利用率は低く, 不採算であった一方, 病床数に基づいて決められる医師や看護師の確保 が困難であった。そのため，各病院において当直 が月に 8 回に上るなど医師や看護師の労働環境は 悪かったというう。したがって，健全な労働環境を 確保すべく，医療従事者の負担を軽減するために は, 病床数を減らす以外に有効な解決策は残され ていなかった。

医療従事者の不足を解消するという同町が作成 した医療再編実施計画の理念は，その骨子を作成 した医療体制のあり方検討委員会の答申を受けて 決定されたものであった。さらにその答申は，長 崎県離島医療圈組合（現在の長崎県病院企業団）に よる懇話会の提言に沿ったものであった。すなわ ち，新上五島町内の医療施設の病床数を削減する という計画は, 長崎県病院企業団を運営する長崎 県と島原地域，五島地域および対馬地域の 1 県 5 市 1 町による意思決定を反映したものである。こ のことから，長崎県離島医療圈組合は，新上五島 町を含めた島嶼部の医療体制のあり方を決定する うえで少なからぬ役割を果たした。

長崎県病院企業団は，地方公共団体が経営する 地方公営企業である病院事業として, 企業として の経済性の発揮と公共の福祉の増進という公共性 の両立に努めている。特に同企業団の運営する病 院は公立病院という性格上，長崎県医療計画に基 づいて，地域に不足している離島や僻地に㧍ける 医療の安定的な確保を図る役割を担ってきた。そ のため, 上記の本来一般会計が負担すべき経費と の負担区分を前提としたうえでの独立採算制とな っている。

それにもかかわらず，長崎県の環境要因の変化 として, 医療供給地域における人口の減少が, 病 
院収入を大きく左右しており, 結果として病院経 営の不確実性を高めている。そのため, 長崎県の ように人口が減少傾向にある状況下において, 患 者をいかに確保し, 病床の稼働率をいかに高めて いくかが長崎県の病院経営にとって重要な課題と なっている。離島医療圈組合の設立以前に, 医療 施設は慢性的に不足し，医療の確保が困難を極め ていたため, 同組合が基幹病院の老朽化の解消や 増床, 医療機器の整備などを行うことで各二次医 療圈域の医療の充実を図ってきた経緯がある。長 崎県病院企業団の設立にあたって, 人口減少が著 しく，医師等医療従事者の確保が困難な島嶼部に おいては，医療資源の集約化や機能分担による将 来を見据えた医療供給体制の構築により，地域が 必要とする医療水準の維持を図ることが必要と考 えられ, 構成団体の同意のもと, 離島病院の再編 が進められている。このように, 他地域と比べて 離島を数多く抱えることに起因する長崎県特有の 地理的条件の不利性が, 長崎県病院企業団による 病院経営改革の誘因となっている。

(2)長崎県病院企業団による経営改革 前節で 検討したように，上五島地域の医療供給体制の再 編にあたって, 長崎県病院企業団は主導的な役割 を果たした。離島における不採算の医療を担って いくうえで，国の社会保障政策の充実に加えて， 長崎県病院企業団による経営改善に向けた継続的 な取組みが不可欠であった。そこで以下に，長崎 県病院企業団の決算状況も踏まえながら, 経営改 革の効果と実現の要因を考察する。

ほとんどの公立病院は, 地方公営企業に位置付 けられ, 地方公営企業法の財務規定等が適用さ れる。同法では, 原則独立採算制が適用されるが, 受益者負担だけでは回収困難な経費については, 自治体の一般会計等で負担することが可能となっ ている。病院企業団の病院経営においても, 公的 資金の投入は，長崎県や構成市町からの繰入金と して正当化されている。 そのため, 公立病院の経営状況は, 厚生労働省
によって隔年で実施される報酬改定に加えて, 総 務省による交付税の配分など地方財政措置のあり 方に大きく影響される。前者では2001年から 2006 年の小泉純一郎政権のもとで進められた医療制度 改革の一環で, 総額の診療報酬改定率が, 2002 2008年度においていずれもマイナスであった。一 方，2009年に民主党政権に交代して以降，医師の 労働条件の緩和を目的として，訬療報酬改定率は 2010年度および2012年度においてプラスに転換し た。

後者では, 許可病床 1 床当たりの普通交付税が 県では1996年度の 78.6 万円から 2008 年度の 48.2 万 円，市町では同期間に 74.0 万円から 48.2 万ととそ れぞれ減少傾向を示した。しかし，その後年度と ともに単価が引き上げられた結果，2012年度には 県, 市町とも71.3万円に増加した。

その結果, 公立病院に扔ける全国平均の経常収 支比率は, 診療報酬の増加による患者単価の増加 と, 病床利用率の向上による人件費当たりの収益 の増加によって改善傾向にある。2006年度から 2007年度にかけて95.2\%にまで低下した経常収支 比率は，2011年度に $100.2 \%$ まで上昇した（第 4 図)。

長崎県病院企業団への構成団体負担金の推移を みると, 公立病院に対する地方交付税措置の拡充 により2009，2010年度は増加しているが，交付税 を除く構成団体の実質的な負担はこの間も含め減 少傾向にある (第 5 表)。すなわち, 県の一般財源 は，2004年度の 25.4 億円から 2012 年度の 13.0 億円 へと約半減した。また, 市町の一般財源は, 2004 年度の7.0億円から 2012年度の5.9億円へと微減し た。一方, 地方交付税は, 旧県立病院については 長崎県へ, 旧離島医療圈組合病院については離島 の 3 市町へ配分されている。その結果, 交付税の 負担金総額に占める割合は, 2004年度当時 4 割程 度だったものが，2012年度には 6 割を占めるに至 つた。

長崎県病院企業団の経常収支比率をみると, 公 


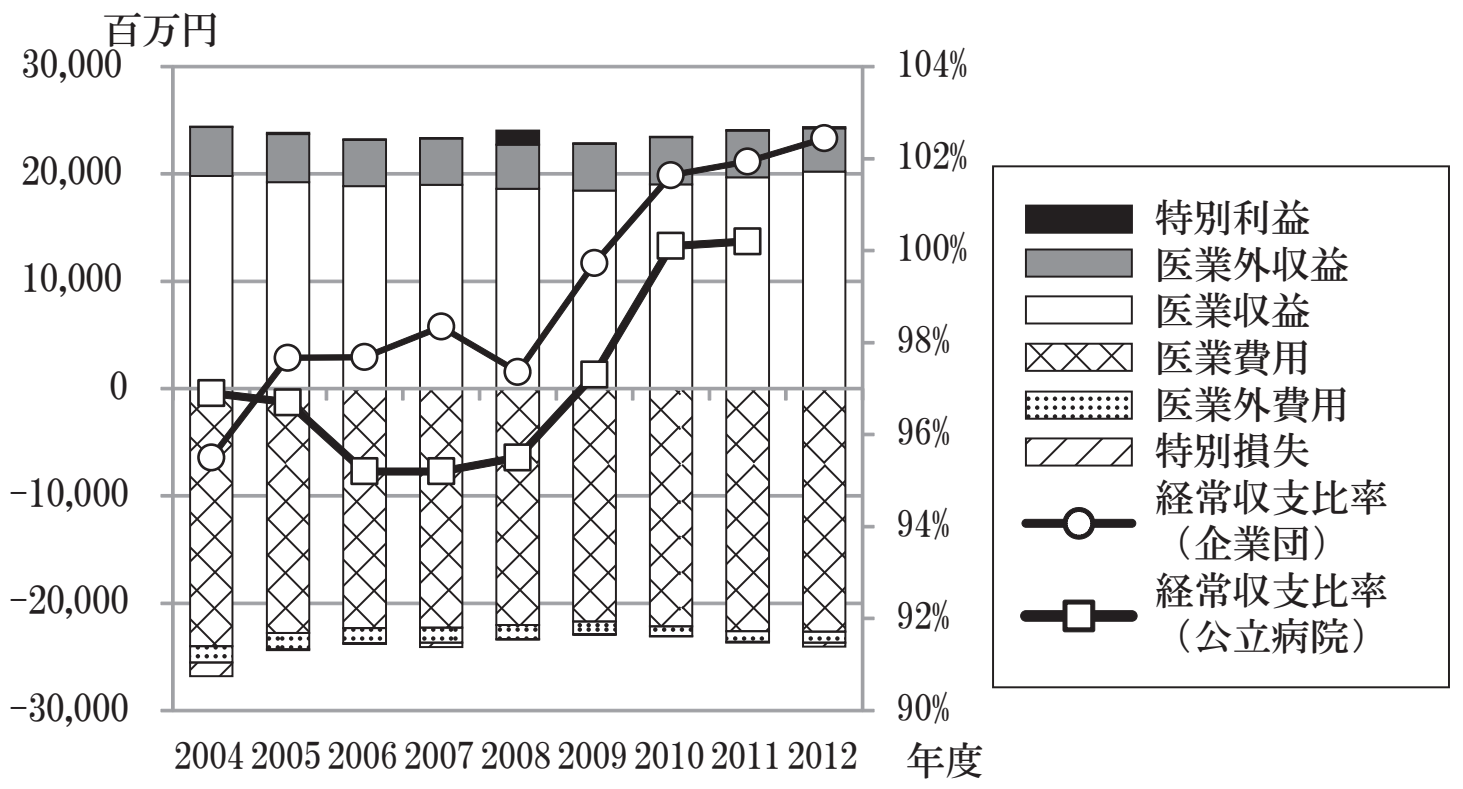

第 4 図長崎県病院企業団決算の推移

Figure 4. Financial data of Nagasaki Hospital Agency

資料：長崎県病院企業団から提供された組織体制や経営概況を解説した資料により作成。

第 5 表 長崎県病院企業団への構成団体負担金の推移

Table 5. Changes in contribution of affiliated bodies for Nagasaki Hospital Agency

\begin{tabular}{c|c|c|c|c}
\hline \multicolumn{5}{|c}{} \\
\hline 年度 & 県 (一般財源) & 市町 (一般財源) & 交付税 (県·市町) & 合計 \\
\hline 2004 & 2,543 & 696 & 2,462 & 5,701 \\
2005 & 2,173 & 744 & 2,413 & 5,330 \\
2006 & 2,082 & 759 & 2,381 & 5,222 \\
2007 & 1,832 & 615 & 2,163 & 4,610 \\
2008 & 1,842 & 601 & 2,110 & 4,553 \\
2009 & 1,475 & 587 & 2,709 & 4,771 \\
2010 & 1,199 & 550 & 3,129 & 4,878 \\
2011 & 1,293 & 535 & 3,023 & 4,851 \\
2012 & 1,297 & 591 & 2,799 & 4,687 \\
\hline
\end{tabular}

資料：長崎県病院企業団から提供された組織体制や経営概況を解説した資料により作成。

立病院全体の平均值よりも増加の程度が大きく, 2012年度に $102.4 \%$ まで上昇した（第 4 図）。繰入 金を含めた医業外収益が減少傾向にあるにもかか わらず, 経常収支比率が改善している要因として, 高い医業費用の継続的な削減があげられる。医業 費用から医業収入を差し引いた医業損失は，直近 の 5 年間で約 10 億円縮小した。上五島地域に限定 すると，過去 5 年間の医業損失は，1.8億円縮小 した。 2 病院の無床診療所化による人件費の削減
がその主な要因と推察される。

こうした一連の経営改革は，前企業団長のトッ プダウンの経営判断によるところが大きい。旧離 島医療圈組合においては，金下の 3 組合がそれぞ れ別会計を採用していた。一方，当時は，長崎県 知事が組合長を務めており，意思決定が事務的に なる傾向があったという。しかし，企業団の設立 以降，医師として勤務経験がある企業長による判 断が可能になった。前企業団長および現企業団長 
はいずれも，長崎医療センターのセンター長を務 めた経験があり，不採算である離島医療を維持す るための課題を熟知していた。また 4 つの一部事 務組合と 1 つの県立病院の会計処理を統一するこ とで，スケールメリットを生かした医薬品納入な どによるコスト削減を図ることが可能になった。 実際，企業団が設立された 2009 年度以降，企業団 の医薬品や医療機器などの共同購入事業が開始さ れたことによって，2008年度比で毎年度 1 億円前 後が削減された。このように, 長崎県病院企業団 の経営改革は，企業団の設立に伴う組織体制の変 更によって，医師の勤務環境に配慮しながら経済 性を発揮させたことによって実現した。

\section{$\mathrm{V}$ おわりに}

本稿は，長崎県上五島地域を事例として，条件 不利地域である離島における医療供給体制を検討 し, 上五島地域内外の各主体の取組みから, どの ようにして経営の合理化を図りながら医療サービ スの公平性の維持を図っているのか考察した。

福祉国家の退場にともなって，地方分権という 名目のもと, 新自由主義化した福祉サービス供給 におけるローカル・ガバナンスの重要性が指摘さ れている。しかしながら，国民皆保険制度下にお いて, ナショナルミニマムとしての医療供給の公 平性を担保するうえで，国家の責任は依然として 大きい。実際に，近年の国の交付税措置，地域医 療再生基金や診療報酬プラス改定は，医療機関の 収支改善に大きく寄与した。こうした国策に加え て，医療計画を策定する各都道府県や，基礎自治 体を超えた受療圈をもつ高度かつ専門的医療を実 施する医療機関の経営行動を含めた，より広域の スケールにおけるガバナンスのあり方についても 考慮する必要がある。

本稿の事例に照らせば, 離島医療を維持可能と した地域固有の要因として, その時々の社会保障 政策の動向に左右されず，健全な医師の勤務環境 と経済性の確保を優先してきた長崎県, 本土医療
機関, 病院企業団, 関係市町による協調行動を指 摘できよう。こうした協調行動によって，上五島 地域の離島であるがゆえの，時間的，距離的制約 を克服するために不可欠な，ICT の活用と救急 搬送体制の確保が可能になった。医療施設の立地 をほとんど変えることなく，島内の医療資源の集 約化と医療サービスの維持の両立を目指すこうし た仕組みは, 従来の施設の最適配置研究では十分 に考慮されてこなかった, 物理的距離の制約を改 善する方策の一つとして有効である。

その結果, 上五島地域以外の二次医療圈を含む 長崎県全域を管轄地域とする主体による広域的な 対応によって, 離島における医療供給体制が維持 されていた（第 5 図）。たしかに，市町村合併の結 果, 基礎自治体の管轄範囲は二次医療圈の圈域と ほぼ致したため, 自治体の医療政策と二次医療 圈の医療計画との整合性は高まった。しかし，新 上五島町と小值賀町の 2 町で構成される上五島医 療圈は, 長崎県によって, 医療法のもとで入院医 療を完結させるための圈域として便宜上設定され たものであり, 離島で構成される二次医療圈の医 療需要をすべて自圈内で充足するには限界があっ た。県や本土に立地する医療機関の支援なくして, 離島の自治体がその管轄地域における医師の勤務 環境を改善したり，医療施設を集約したりするこ とは公平性の維持の点からきわめて困難な構造な のである。

事実，医療資源を動員しょうと島内外の複数の 主体が介在した現象は，離島を中心とする条件不 利地域においてのみみられ，長崎医療圈や佐世 保・県北医療圈など長崎県内でも本土の医療資源 が恵まれた圈域ではみられない。すなわち，長崎 県上五島地域の医療供給体制の再編成は, 基礎自 治体や二次医療圈といったローカル・スケールで は対処できない地理的条件において，本土を含め た長崎県といったより広域のスケールで対処しよ うとした，ガバナンスの見直しをはらんだプロセ スといえる。 


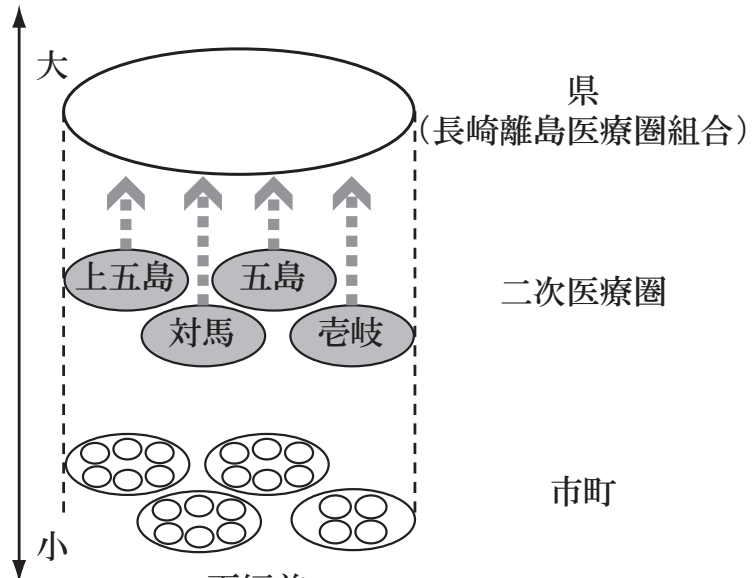

再編前

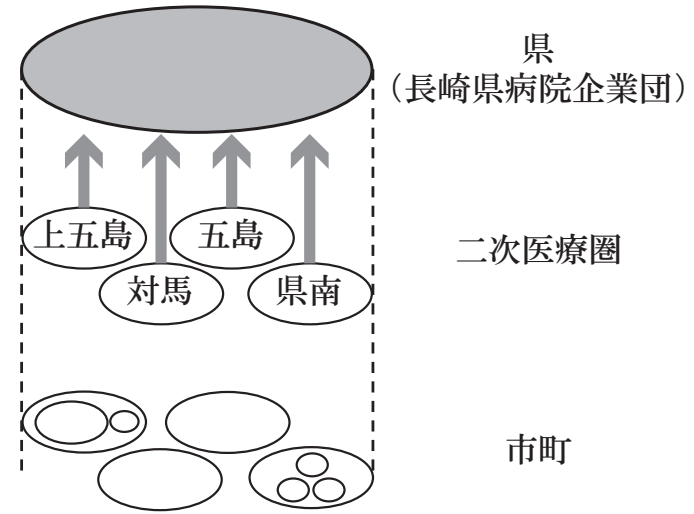

再編後

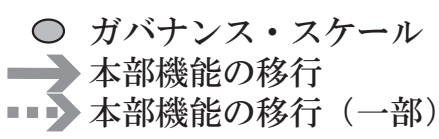

第 5 図長崎県の離島における医療供給体制の再編成

Figure 5. Health care restructuring in the isolated islands of Nagasaki Prefecture 注：県南医療圈は島原市, 雲仙市, 南島原市で構成される。 資料：聞取り調査により作成。

以上のように，島外の支援を受けて，医療機関 の経営改善を図りつつ, 公平性の維持に努めても なお，医療サービスの地理的偏在が残存する可能 性がある。上五島地域における今後の課題として, アクセシビリティ改善のための交通利便性の確保 や，在宅医療支援のための多職種間の情報共有を 指摘できる。これまでの医療供給主体の経営方針 に鑑みると，いかにニーズがあろうと，医師の勤 務環境の確保を最優先するならば，本土並みの医 療供給体制を維持するための費用を捻出し続ける のは容易ではない。今後, 供給主体の論理と住民 の生活の論理のバランスをめぐって, 経済性のい っそうの追求のために，多様な供給主体が，地域 住民といかに合意形成を図っていくかがクリアす べき政策的課題になってこよう。いずれにせよ， 本稿の事例は，二次医療圈を入院医療の基本的な 地理的範囲としてきた現行の地域医療計画におけ る画一的な対応の限界を如実に表している。

本稿において得られた知見を，地方都市や中山 間地域など他の条件不利地域に敷衍できるかどう
かについては慎重な検討を要する。離島はその隔 絶性と狭小性という地理的特性から，上記した地 域よりも都市機能の集約化による経済性が発揮し にくい。そうした不利な状況に置かれているから こそ，島内外の関係主体による対応が図られたの であった。しかしながら，全国的に医師不足と高 齢化が進展する現在，他の条件不利地域において も，医療関連施設の空間的分布のみならず，関係 主体の行動を地理的条件の差異を踏まえて分析す る必要があろう。

例えば, 国立社会保障・人口問題研究所の将来 推計人口（2013年 3 月推計）によると, 離島で構成 される新上五島町，対馬市，五島市などにおいて， 2020年前後をピークに65歳以上の高齢者の絶対数 が減少に転じる。したがって，本稿の事例は，医 療需要の減少を見越した医療供給体制の縮減対策 ととらえることもできよう。一方，大村市におい ては，同值が2040年まで一貫して増加すると見込 まれており, 医療需要の増加に合わせた医療と福 祉の供給体制の整備が急務であることは想像に難 
くない。大村市と同じ二次医療圈を構成する近隣 4 市町は同值のピークを先駆けて迎えることから, 現在の医療供給体制のままでは, 自圈内で増加す る医療需要を充足するのは困難になると推測でき る。しかし, 圈外と地理的に連続していることか ら, 二次医療圈を超えた広域的な対応が図りやす い。今後, こうした問題は, 高齢者の絶対数が大 きい大都市圈でより切実になると考えられる。

このように，多様な地理的条件と空間スケール に焦点を当てた考察は，関係主体の役割と連携の 態様を明らかにし，とかくローカルなスケールで のみとらえられがちな医療供給体制の再編成プロ セスを体系化することにつながる。以上の試みは, 医療需要のある地域に広域的かつ柔軟に対応して 医療サービスの公平性を維持しつつ, 持続可能な 社会保障を確保するための具体的な支援策の提言 にも寄与するものと考えられる。

〔付記〕長崎県福祉保健部医療政策課, 新上五島町役 場, 国立大学病院機構長崎医療センター, 長崎県上五 島病院, 長崎県病院企業団, 大村東彼薬剤師会の方々 をはじめ, ご協力くださった皆様には貴重なお話およ び資料をいただくなど格別な配慮を賜りました。この 場を借りて感謝いたします。なお，この研究成果の一 部は, 2013年日本地理学会秋季学術大会および経済地 理学会関東支部2013年12月例会において発表した。本 稿の執筆にあたっては, 科学研究費補助金 (若手研究 (B)『情報技術の活用にともなう地域医療の再編成に関 する地理学的研究』研究課題番号: 24720372 , 研究代 表者: 中村 努), (基盤研究(B)『デジタル時代の情報 生成・流通・活用に関する地理学的研究』研究課題番 号：23320187, 研究代表者：和田 崇）を使用した。

(高知大学・教育学部)

注

1）（1酒川 茂「広島県に掞ける医療施設の最適立地」 人文地理 $32-5,1980,385-406$ 頁。(2)濱里正史「医療 機会へのアクセシビリティからみた沖縄本島地域の空 間構造」GIS 一理論と応用7-2，1999，35-42頁。(3)関 根智子「近接性の時空間的安定度の分析一千葉県松戸 市の眼科医院を事例として一」地理学評論 $76-10$, 2003，725-742頁。(4)三原昌巳「福島県に抢ける初期 医療サービスの地域差一物理的アクセシビリティと受
療行動の関係から一」人間文化創成科学論叢 12,2009 , 201-209頁。

2）フードデザート問題については，イギリスではリグ レー (Wrigley, Neil) ら, 日本では岩間らの一連の 研究がある。(1) Wrigley, N., Warm, D. and Margetts, B., 'Deprivation, diet, and food-retail access: findings from the Leeds 'food deserts' study', Environment and Planning A, 35-1, 2003, pp. 151-188. (2)岩 間信之編『改訂新版フードデザート問題一無縁社会が 生む「食の砂漠」一』農林統計協会, 2013（初版 2011)。

3）特に2000年の介護保険制度導入をきっかけに，福祉 サービス供給の地域差とその要因を明らかにした研究 が数多く発表されている。(1)宮澤 仁「関東地方にお ける介護保険サービスの地域的偏在と事業者参入の関 係一市区町村デー夕の統計分析を中心に一」地理学評 論76-2，2003，59-80頁。(2)杉浦真一郎『地域と高齢 者福祉一介護サービスの需給空間一』古今書院，2005。 (3)畠山輝雄「介護保険地域密着型サービスの地域差と その要因」地理学評論85-1，2012，22-39頁。

4）（1)宮澤 仁「福島県西会津町に扔ける健康福祉のま ちづくりと地域活性化」人文地理58-3，2006，235252頁。(2)稲田七海「介護保険制度の受容に伴う高齢 者ケアと相互扶助の変容一上㼪島旧里村を事例として 一」人文地理 61-4，2009，328-347頁。(3)佐藤正志 「周辺地域に抢ける自治体公共サービス民営化の特徴 一青森県三戸町の包括業務委託の事例一」地理学評論 83-2，2010，131-150頁。(4)前田洋介「ボランタリー 組織を主体としたローカル・ガバナンスの形成とその 地理的特徽一名古屋市の地域防災を事例に一」人文地 理64-4，2012，319-336頁。

5）中村 努「ICT を活用した医薬品流通システムの構 築過程一川崎市北部の事例一」地理学評論86-3，2013， 288-299頁。

6）中村 努「離島に打ける医薬品流通システムと医薬 品卸の役割一長崎県五島列島の事例一」季刊地理学 63 $-1,2011,1-16$ 頁。

7) 前掲 6 )。

8）長崎県『長崎県医療統計』長崎県，2010。

9）（1)山崎孝史『政治・空間・場所一「政治の地理学」 にむけて一 (改訂版)』ナカニシヤ出版, 2013（初版 2010), 135 頁。(2) Brenner, N., 'Globalisation as reterritorialisation: the re-scaling of urban governance in the European Union', Urban Studies, 36-3, 1999, pp. 431-451.

10）本稿では，新上五島町役場健康保険課から提供され た医療機関の配置を示した資料に加え，長崎県病院企 業団から提供された企業団案内パンフレット抄よび組 織体制や経営概況を解説した資料, 長崎県福祉保健部 医療政策課から提供された資料を使用した。

11）長崎県新上五島町「位置・地勢」2010, http://official. shinkamigoto. net/index.php?itemid $=211 \&$ catid $=7$ 2014年 3 月 20 日閲覽。

12）長崎県新上五島町『新上五島町地域公共交通総合連 携計画』長崎県新上五島町，2011，1 頁。

13）上五島病院への聞取り調査による。

14）財団法人 九州地域産業活性化センター『小規模市 
町村の連携による行政サービスの提供方策のあり方』 財団法人 九州地域産業活性化センター, 2010, 80頁。

15）八坂貴宏「離島・へき地医療からみえる地域医療再 生のヒント」日本老年医学会雑誌46-6，2009，496499頁。

16）中里未央ほか「長崎県の離島・へき地医療と五島市 の高齢者医療」五島中央病院紀要 9，2007，29-38頁。

17）長崎県上五島病院「当院の概要, 特色」 2014 , http://www.kamigoto-hospital.jp/residents/about. html 2014年 3 月 7 日閲覧。

18）長崎県福祉保健部医療政策課より提供された資料に 基づく。

19）前掲17)。

20）長崎県新上五島町『新上五島町財政運営適正化計 画』長崎県新上五島町，2011，4 頁。

21）新上五島町医療体制のあり方検討委員会『新上五島 町医療体制のあり方検討委員会報告書 (答申書)』新 上五島町医療体制のあり方検討委員会，2008，3 頁。

22）長崎県病院企業団「沿革」2014, http://www. nagasaki-hosp-agency.or.jp/nha/enkaku.html 2014 年 6 月 15 日閲覧。

23）総務省「公立病院改革ガイドライン」2007, http:// www.soumu.go.jp/main_sosiki/c-zaisei/hospital/ pdf/071224_zenbun.pdf 2014年 3 月17日閲覧。

24）前掲21）， 1 頁。

25）長崎県新上五島町『新上五島町医療再編実施計画』
長崎県新上五島町，2009，2 頁。

26）新上五島町役場への聞取り調査による。

27）長崎県病院企業団への聞取り調査による。

28）上五島病院への聞取り調査による。

29）福岡政経調査会「離島組合 9 病院・県立 2 病院：09 年春再編·長崎県!」2008, http://fukuoka-seikei. com/08-0619-f2.htm２014年 6 月15日閲覧。

30）近藤隆史・岡田裕正「地方自治体立病院の経営改革 の現状と課題一長崎県立病院のケースを中心として 一」経営と経済88-3，2008，299-330頁。

31）長崎県離島医療医師の会「長崎県の離島医療の歩 み」2014, http://mokuseikai.org/ritoiryo/ 2014 年 3 月 7 日閲覧。

32）長崎県病院企業団『長崎県病院企業団中期経営計画 (平成24年度～平成28年度)』長崎県病院企業団, 2012 5 頁。

33）山内康弘「自治体病院の制度的位置付けと財源問 題」国際公共政策研究13-2，2009，51-63頁。

34）堀真奈美「医療供給体制における自治体病院のあり 方」会計検査研究 $36,2007,61-76$ 頁。

35）経常収支比率 $=$ 経常収益 $/$ 経常費用 $\times 100$ 。経常収 支比率は公立病院改革ガイドラインが指定している経 営指標のうちの一つで, 総務省は平成 23 年度までに同 值が100\%を上回ること（経常収支の黒字化）を想定 した経営の効率化を求めている。前掲23)。

36）長崎県病院企業団への聞取り調査による。

\title{
Mechanism of Health Care Restructuring in the Kamigoto District, Nagasaki Prefecture
}

\author{
NAKAMURA Tsutomu \\ Faculty of Education, Kochi University
}

This study discusses the health care system in the Kamigoto District, Nagasaki Prefecture, which is an isolated island and is treated as a disadvantaged area. The study considers the behavior of each health-related actor inside and outside of the region according to the way in which the actor seeks rationality and equitability.

Through health care policy for the isolated islands, the minimum necessary health care services have been maintained with the support of the mainland. The health care policy for the isolated islands in Nagasaki includes the operation of medical institutions, retention of doctors, plans for transportation by helicopter, and the introduction of a medical information system. Nagasaki Prefecture has strengthened health care services in the isolated islands with the help of the universities and local governments. The Nagasaki Hospital Agency, which was established in Nagasaki Prefecture, was intended to operate hospitals together with the cities and towns in Shimabara, Goto, and Tsushima Districts in April 2009. The agency adopts a special district authority that fully applies the Local Public Enterprise Act, and it operates two prefectural hospitals and nine group hospitals. Three hospitals located in Shin-Kamigoto Town were put into operation by the newly created Nagasaki Hospital Agency.

The implementation of the health care restructuring plan of Shin-Kamigoto Town proceeded 
as planned. Each health-related facility in the town clarified its function, and all facilities were closely coordinated with each other, with a view to maintain the current service level and improve management. Inpatient medical care was centralized at Kamigoto Hospital as a local base. In addition, the beds at Arikawa Hospital (currently Arikawa Medical Center), Shin-Uonome Clinic, Wakamatsu Clinic, and Narao Hospital (currently Narao Medical Center) were eliminated. As a result, the total number of beds in the Kamigoto District was reduced by almost half, i. e., from 334 to 186 . However, the mainland provides supplementary support because no medical institution has the capacity to supply tertiary and psychiatric inpatient medical care in Shin-Kamigoto Town. A prerequisite for the smooth implementation of the plan is cooperation among Shin-Kamigoto Town, the Nagasaki Hospital Agency, medical institutions on the mainland, and Kamigoto Hospital in maintaining health care services on the isolated island.

As described above, the large scale response maintained the health care system on the isolated island by the actors whose jurisdictional area covers all parts of Nagasaki Prefecture encompassing the secondary medical areas outside of Kamigoto District. The phenomenon that multiple actors mobilized health care resources to address the scarcity of such resources is specific to a disadvantaged area. Hence, the process of restructuring health care in the Kamigoto District was accompanied by a review of governance, in which the disadvantageous geographical conditions were overcome not through local governance such as the municipality or a secondary medical area, but by expanding the scale to the level of Nagasaki Prefecture.

Key words: health care system, isolated island, health care facility, secondary medical area, Kamigoto District 